https://doi.org/10.15407/frg2020.03.187

UDC 581.1

\title{
PHYSIOLOGICAL PECULIARITIES OF SUNFLOWER BORON NUTRITION
}

\author{
V.V. MORGUN ${ }^{1}$, I. CAKMAK ${ }^{2}$, V.V. SCHWARTAU ${ }^{1}$, L.M. MYKHALSKA ${ }^{1}$ \\ ${ }^{1}$ Institute of Plant Physiology and Genetics, National Academy of Sciences of \\ Ukraine \\ 31/17 Vasylkivska St., Kyiv, 03022, Ukraine \\ e-mail: victorschwartau@gmail.com \\ ${ }^{2}$ Faculty of Engineering \& Natural Sciences, Sabanci University \\ 34956, Tuzla, Istanbul, Turkey
}

\begin{abstract}
Although the importance of plant nutrition with boron was established almost a hundred years ago, the physiological peculiarities of its activity continue to be among the discussed. The boric fertilizers market in Ukraine is overloaded by advertising propositions and there are practically limited results of correct boron nutrition efficiency determination. Traditionally, since the early 1990s, the focus on plant nutrition in Ukraine has been given to nitrogen. However, low levels of nitrogen utilization by crops indicate that information on the physiological mechanisms of cultivated plants nutrition is not enough. And, practically, the issues of cultivated plants nutrition by other important elements, first of all - boron, remain out of focus. In Ukraine, areas under boron-dependent crops exceed 10 million hectares: sunflower, winter and spring rapeseed, sugar beets, potatoes, etc. Boron in nutrition systems is also required on soybean, cereals and maize. Cultivated plant's boron deficiency is observed in all soil and climatic zones of Ukraine. The aim of this research was to explore promising for Ukraine form of boron mineral fertilizers for sunflower nutrition, a culture that occupies the largest area in the country among all and boron-sensitive crops. Studies have shown that use of boron fertilizers in crop production of Ukraine is important for improving the productivity of boron-sensitive crops, mainly sunflower, and the basic introduction of slowly soluble boric fertilizer (Colemanite, Ulexite, etc) into the soil will significantly reduce seedling damage from phytotoxic effects of boron and increase productivity of boron-sensitive cultivated plants.
\end{abstract}

Key words: boron, sunflower, yield, phytotoxicity.

The biological significance of boron in plant nutrition was first established in 1923 [1]. Boron (B) belongs to group 13 period 2 of the periodic table of elements and has intermediate properties between metals and non-metals [2]. Despite its low levels of presence in nature, the element is widespread both in the lithosphere and in the hydrosphere [3]. Although numerous studies have revealed the need for an element, its presence in soils and plants was identified, long-term experiments with boron fertilizers were conducted, to date physiological mechanisms of boron nutrition 
are among the few issues studied. It should also be noted that the market for boric fertilizers in Ukraine is dominated by advertising propositions, and there are practically limited results of randomized experiments on the correct determination of the boron nutrition efficiency.

Traditionally, since the early 1990s, the focus on plant nutrition has been given to nitrogen. However, low levels of nitrogen utilization by crops indicate that information on the physiological mechanisms of cultivated plants nutrition is not enough. And, practically, the issues of nutrition of cultivated plants with other important elements, first of all - boron, remain out of focus. In Ukraine, areas under boron-dependent crops exceed 10 million hectares: sunflower, winter and spring rapeseed, sugar beets, potatoes, etc. Boron in nutrition systems is also required on soybean, cereals and maize. Boron deficiency in cultivated plants is observed in all soil and climatic zones of Ukraine. Visual symptoms of boron deficiency are observed on dicotyledonous species, maize (Zea mays), and wheat (Triticum aestivum) at element concentrations in tissues less than 20-30, $10-20$, and $10 \mathrm{mg} / \mathrm{kg}$ of dry matter, respectively [4].

Boron deficiency in cultivated plants has been found to be significantly more widespread than other trace elements [4]. However, for the conditions of Ukraine, we believe that the importance of boron deficiency in crops is not inferior to the large-scale manifestations of copper and zinc deficiency.

Boron content in the soils of Ukraine. Boron can be present in the soil in several forms. In most soils of Ukraine, with a $\mathrm{pH}$ value of 5.5 to 7.5, the predominant form of boron is boric acid and borate ion. Boron is able to absorb on particles of clay minerals, and on organic constituents of soils. The element has a high affinity for binding to iron or aluminum oxides. Boron absorption on clay minerals is reversible. The relationship between boron concentration in soil solutions and levels of element absorbed by soil particles is influenced by the $\mathrm{pH}$ and temperature, the soil salt index, as well as by their physical and chemical properties.

For most soils B is a deficient element, and for some plant species there is a manifestation of its global deficiency. For a number of borondependent crops, including sugar and fodder beets, celery, sunflower, legumes, apple trees, boron deficiency is observed annually on large areas. From the list of specific symptoms of deficiency, there are inhibition and abnormal development of growth points, bluish-green color of young leaves, and decrease in fertility levels.

The content of boron mobile form in the soils of Ukraine ranges from the minimum (trace) amount in the sod-podzolic sandy soils of the Polissya to $3.37 \mathrm{mg} / \mathrm{kg}$ of soil - in the saline black earths. Thus, Polissya soils should be attributed to soils with pronounced boron deficiency, sodpodzolic surface-polluted soils of the Carpathians are assigned to the group with an average boron content $-0.3-0.5 \mathrm{mg} / \mathrm{kg}$ of soil. Forest-Steppe soils with a boron content of $0.18-2.30 \mathrm{mg} / \mathrm{kg}$ of soil are classified as rich in this element. The obtained data indicate the lack of zinc mobile form in most of the surveyed soils, boron - in sandy and sandy soils of Polissya. The content of other trace elements in the soil corresponds to medium and high levels. Up to $25 \%$ of arable land has a low boron content, which causes a deficit of the element in nutrition systems [5]. 
Boron promotes the consumption of calcium by plants from the soil. Boron deficiency in soil impairs calcium absorption by plants, even at its high soil concentrations. With a high supply of crops with potassium, the need for boron increases. The mobility of boron in soil is adversely affected by liming. Limestone fertilizers containing $\mathrm{CaCO}_{3}$ reduce the content of water-soluble boron in the soil, whereas the pulverized shale ash, consisting mainly of $\mathrm{CaO}$, increases its availability due to the destruction of mineral and organic boron compounds. However, in the latter case, leaching of soluble boron compounds from the soil is observed. Consequently, limestone boron is available in acidified soils. Boron deficiency is most commonly observed on carbonate soils and wetlands, and is worsened in dry years, in particular in 2019 , as well as in years with high rainfall during the growing season, and with excessive nitrogen fertilizer application.

Physiological and biochemical role of boron in plant nutrition. It should be noted that there is a significant contradiction in the data on determining the need for boron, which is based on the removal of the element with the yield of the main boron-dependent crops. Crops take up boron throughout the growing season. The average yields of boron with a crop of sugar beet roots of $8-10 \mathrm{t} / \mathrm{ha}$ are $80-90 \mathrm{~g} / \mathrm{ha}$, and with a rape seeds crop of $1 \mathrm{t} / \mathrm{ha}-120-200 \mathrm{~g} / \mathrm{ha}$, with sunflower seeds crop 1.0-1.5 t/ha 120-200 g/ha. However, this data cannot be the basis for the development of boron nutrition systems. To obtain even average crop levels, cultivated plants require significantly higher amounts of boron fertilizers. According to [6-8], up to $3-4 \mathrm{~kg} / \mathrm{ha}$ of element should be applied to provide sunflower crops with a yield above $3 \mathrm{t} / \mathrm{ha}$.

The regulation of boron uptake and translocation in plants is provided by two transmembrane transporter families: the Nodulin26-like Intrinsic Protein (NIP) and BOR transporter family [9]. In the presence of boron, the synthesis and transport of carbohydrates, growth substances (hormones) and ascorbic acid from the leaves to the reproductive organs and to the roots are carried out. Boron is needed for plants to grow and develop meristematic tissues. Deficiency of boron in plants leads to the destruction of young tissues, the suspension of root system and stems growth, death of plant growth points. Boron promotes growth of pollen tubes in flowers and their pollination. Boron deficiency causes a number of plant lesions - apical chlorosis of plant growth point, dry rot and root rot of root crops, apical root ulcer of sugar beet root. With boron-dependent deficiency in boron-dependent crops, particularly rapeseed, the root system deforms, necrotic spots appear, growth points development inhibit, stems crack, flowering suspend, and rape wintering worsening.

Poor boron provision of plants causes impaired anatomical structure, poor xylem development, the main parenchyma phloem fragmentation, and cambium degeneration. The root system develops poorly and is affected by rot, bacteriosis and other root diseases.

Boron differs from other trace elements in its physiological significance. Recent works have identified the following processes in plants that occur in the presence of boron: cell wall structures formation; membrane structures functions; metabolic activity, including signaling functions by interaction with calcium; carbohydrates metabolism and sugars transport across membranes; synthesis of nucleic acids (DNA and RNA) and phytohormones. 
The latter may indicate the involvement of boron in numerous metabolic processes in plants. Therefore, element deficiency causes a pleiotropic effect. It has been suggested that since boron can form strong bonds between cis-hydroxyl derivatives, the basic significance of boron in plant life is the stabilization of molecules with cis-diol groups, which converts them into active forms regardless of their specific function [10-12].

Isolation and characterization of rhamnogalacturonan-II-boron complexes (RG-II-B) demonstrated cross-links between apiose residues in pectin, confirming the role of boron in cell wall formation [13]. There is still no direct evidence for the involvement of boron in the formation of biological membranes, but the binding of boron to hydroxyl-containing components of phosphoinositides, glycoproteins and glycolipids may be related to the regulation of membrane-level transport processes in borondeficient plants.

Recent decade studies have shown that the mobility of boron in plants cannot be the basis for providing of plant different parts and organs by foliar applications during vegetation. Boron can form strong complexes with different molecules carrying cis-diol groups in appropriate spatial configurations. B-complexes with apiose, ribose, NAD, S-adenosylmethionine (SAM), phenols, mannitol, sorbitol, sucrose, amino acids and larger molecules such as glycopeptides and glycoproteins have been detected [14, 15]. Boron is transported in the form of a complex with polyols in species in which polyols are the main photoassimilates.

Many cultivated plants, as well as tree crops, produce polyols in photosynthetic processes. However, information on the amounts of polyol synthesis in cultivated plants is still insufficient to determine the levels of borates transport in plants.

Boron is not evenly distributed throughout the plant. Boron accumulates more in leaves, buds, flowers, its main location - pollen, ligament, stamens. Less boron contain in roots and very few - in stems. The boron is not reutilized between old and young leaves of the plant. This provision is important due to the fact that boron is introduced in foliar fertilizing in the vast majority of Ukrainian farms.

Interaction of boron with other elements. The effects of boron on the absorption of other nutrients by plants are associated with changes in membrane permeability and the state of intracellular colloids. The interaction of boron with other trace elements is somewhat controversial. For example, the predicted boron antagonism with $\mathrm{Cu}, \mathrm{Cr}$, Mo, and $\mathrm{Mn}$ may be related to the indirect effect that occurs when growth is increased and therefore to the increased need for these trace elements. The antagonism of Fe and B is the result of an increase in the accumulation of B in the roots when the Fe flux from the soil is increased. The antagonism of B and Si is a consequence of the competition of silicate ions with B at adsorption, and this reaction is observed both in the soil medium and in root tissues.

The relationship between $\mathrm{B}$ and $\mathrm{Ca}$ is especially common. Plants develop normally under the condition that there is a certain balance in both $\mathrm{Ca}$ and $\mathrm{B}$ influx, and in their concentrations in tissue. Acidic soils often have a deficiency of boron caused by liming. However, with equal amounts of $\mathrm{Ca}$, the concentration of $\mathrm{B}$ in the tissues is much higher when $\mathrm{CaSO}_{4}$ rather than $\mathrm{CaCO}_{3}$ was introduced into the soil, so the toxic effect 
of this element can be attenuated or prevented by the $\mathrm{Ca}$ introduction in the soil. This phenomenon is explained by both reactions in the soil environment and metabolic processes. It should be noted that the interaction of calcium and boron is observed in plants, bacteria, animals and humans. However, the mechanisms for the interaction of calcium and boron are still under discussion.

Boron reduces the mobility and transformation of phosphorus in the roots. Interaction of $\mathrm{B}$ and $\mathrm{P}_{2} \mathrm{O}_{5}$ in soils prevents the influence of phosphate ions on the migration of $\mathrm{B}$. Other nutrients, particularly $\mathrm{K}$ and $\mathrm{Na}$, influence the B contents in plants through secondary factors associated with increased plant growth or some physiological disorders.

Thus, for the normal development of plants strict control is required over the level of boric uninterrupted nutrition supply, which depends on soil solution $\mathrm{pH}$, temperature and water regimes. Given the fact that under the influence of boron plants bloom and produce seeds earlier, the disease incidence reduces, and seed production increases, there is a need of boron fertilizers adding.

Thus, in numerous scientific literature of the last decade, research of $\mathrm{B}$ nutrition mechanisms is considered as one of the main areas in physiology of plant nutrition and productivity of cultivated plants. The effectiveness of certain forms of fertilizers is discussed, and a comparison of the soil and foliar boron fertilizers effectiveness continues to be practically neglected.

The aim of our work was to explore promising for Ukraine form of boron mineral fertilizers for sunflower nutrition, a culture that occupies the largest area in the country among all and boron-sensitive crops.

\section{Materials and methods}

Field studies were performed on the sunflower hybrid Tutti (Syngenta) in the Experimental Agricultural Farm (EAF) of the Institute of Plant Physiology and Genetics (IPPG) of the NAS of Ukraine (Glevakha village, Vasylkiv district, Kyiv region), as well as on fields of holding company PodillyaLatInvest (Vinnytsia region). The plot area at field experiment was $16 \mathrm{~m}^{2}$. Controls were without treatment, the repeatability of 4-6 times.

Fields soil type of EAF - sods of slightly and medium podzolic unglazed and silt sandy loam, $\mathrm{pH}$ salt $(\mathrm{KCl})$ 5.8. Organic matter content in the soil arable layer $1.8 \%$, phosphorus $25 \mathrm{mg} / \mathrm{kg}$, potassium $30 \mathrm{mg} / \mathrm{kg}$. Fertilizers were applied before the growth season $\left(\mathrm{N}_{32} \mathrm{P}_{32} \mathrm{~K}_{32}\right)$.

Fields soil type of PodillyaLatInvest - grey podzolized coarse-dusty, medium loam. $\mathrm{pH}(\mathrm{KCl}) 5.2$, organic matter $2.91, \mathrm{~N}-102 \mathrm{mg} / \mathrm{kg}, \mathrm{P}-$ $174 \mathrm{mg} / \mathrm{kg}, \mathrm{K}-147 \mathrm{mg} / \mathrm{kg} ; \mathrm{B}-0.33, \mathrm{Mn}-8.65, \mathrm{Cu}-0.82, \mathrm{Zn}-$ $0.71 \mathrm{mg} / \mathrm{kg}$.

The scheme of the 2018 growing season experiment included the control and treatment with boric acid in soil application at $17.5 \mathrm{~kg} / \mathrm{ha}$, and foliar $1.0 \mathrm{~kg} / \mathrm{ha}$, twice during the growing season (BBCH 31-33 and $\mathrm{BBCH} 51-55)$.

The scheme of the 2019 growing season experiment included the control and treatment with boron fertilizers of various types, which made equivalent to $3 \mathrm{~kg}$ of boron per 1 ha, namely: 1) control; 2) Etidot-67 (B $21.0 \%)$; 3) Borax pentahydrate powder (B - $15.1 \%)$; 4) Colemanite 
V.V. MORGUN, I. CAKMAK, V.V. SCHWARTAU, L.M. MYKHALSKA

\begin{tabular}{l|c|c}
\hline \multicolumn{3}{c}{ TABLE 1. Main boron fertilizers in Ukraine } \\
\hline \multicolumn{1}{c}{ Fertilizer } & Formula & Boron content, \% \\
\hline Boric acid & $\mathrm{H}_{3} \mathrm{BO}_{3}$ & $17.1-17.5$ \\
Borax (disodium tetraborate) & $\mathrm{Na}_{2} \mathrm{~B}_{4} \mathrm{O}_{7} \cdot 10 \mathrm{H}_{2} \mathrm{O}$ & 11.0 \\
Solubor DF & $\mathrm{Na}_{2} \mathrm{~B}_{8} \mathrm{O}_{13} \cdot 4 \mathrm{H}_{2} \mathrm{O}$ & 17.5 \\
& & \\
\hline
\end{tabular}

granular $(\mathrm{B}-10.0 \%)$; 5) Ulexite granular $(\mathrm{B}-9.7 \%)$; 6) Borax Pentahydrate granular $(\mathrm{B}-14.2 \%)$; 7 ) boric acid $(\mathrm{B}-17.5 \%)$; 8) Etidot-67 $(\mathrm{B}-21.0 \%)$, twice foliar application during vegetation $(\mathrm{BBCH} 31-33$ and BBCH 51-55).

Fine fertilizers (boric acid and Etidot-67) were introduced by a sprayer at the rate of $200 \mathrm{l} / \mathrm{ha}$ of water. Other fertilizers were scattered, all before sunflower seeds were sown.

In the experiment under laboratory conditions, the seedlings of sunflower plants were obtained in $0.5 \mathrm{~kg}$ vegetation pots on a mixture of soil:sand $-1: 1$. Repeatability $-4-6$ times.

The results were processed statistically in Excel 2019 and Agrostat.

\section{Results and discussion}

The list of the main boron fertilizers on the Ukrainian market is given in Table 1. Solubor DF proposals dominated a few years ago, but are now substantially reduced. It should be noted that numerous organic boric fertilizers are used in crop production on substantially smaller areas, principally for economic reasons.

Economic factors concerning the reduction of fertilizers rates, and attempts to improve the efficiency of their use lead to the dominance of

TABLE 2. Boric fertilizers phytotoxicity to sunflower seedlings when applied in the soil

\begin{tabular}{|c|c|c|c|}
\hline Variant & B content, $\%$ & Dose, mg/pot & $\begin{array}{l}\text { Phytotoxicity at } 14 \text { th day } \\
\text { after sowing, } \%\end{array}$ \\
\hline Control & - & - & 0 \\
\hline \multirow{2}{*}{ Etidot-67 } & \multirow{2}{*}{21.0} & 142.9 & 80 \\
\hline & & 4.8 & 20 \\
\hline \multirow{2}{*}{ Borax Pentahydrate powder } & \multirow{2}{*}{15.1} & 220.5 & 100 \\
\hline & & 7.4 & 10 \\
\hline \multirow{2}{*}{ Granular Colemanite } & \multirow{2}{*}{10.0} & 300.0 & 5 \\
\hline & & 10.0 & 0 \\
\hline \multirow{2}{*}{ Granular Ulexite } & \multirow{2}{*}{9.7} & 309.3 & 30 \\
\hline & & 10.3 & 0 \\
\hline \multirow{2}{*}{ Granular Borax Pentahydrate } & \multirow{2}{*}{14.2} & 211.3 & 100 \\
\hline & & 7.1 & 15 \\
\hline \multirow{2}{*}{ Boric Acid } & \multirow{2}{*}{17.5} & 171.4 & 100 \\
\hline & & 5.7 & 10 \\
\hline & $\mathrm{D}_{0.05}$ & & 7 \\
\hline
\end{tabular}


TABLE 3. Boric acid effect on sunflower (Kyiv region, 2018)

\begin{tabular}{l|c|c}
\hline \multicolumn{1}{c|}{ Variant } & $\begin{array}{c}\text { Phytotoxicity at 14th day } \\
\text { after sowing, \% }\end{array}$ & Yield, t/ha \\
\hline Control & 0 & 4.12 \\
Boric acid, in soil before sowing, $17.5 \mathrm{~kg} / \mathrm{ha}$ & 5 & 4.31 \\
Boric acid, 2 foliar, 1.0 kg/ha & - & 4.14 \\
$\mathrm{LSD}_{0,05}$ & 10 & 0.11 \\
\hline
\end{tabular}

boron foliar treatments in plant nutrition. This way of boron nutrition differs from the nutrition practice in Ukraine 30-40 years ago, when the main boron fertilizer to sugar beet was boron enriched superphosphate.

Among the important factors that limit the introduction of borates before sowing are the high levels of rainfall washing anions, and their high toxicity levels to plants. It should be noted that boron is a unique element in nutrition of plants with very narrow intervals between the manifestations of deficiency and phytotoxicity. However, as discussed above, the presence of calcium ions is an important component of boron toxicity control.

Thus, we have found that under the introduction of boron fertilizer phytotoxic effect was not observed at Colemanite and Ulexite application, even when high doses are implemented (Table 2). It should be noted that these fertilizers are slow-soluble and contain in their composition high levels of calcium.

In laboratory experiment with seedlings the phytotoxicity of Etidote-67 and boric acid was pronounced. A study of the effectiveness of sunflower soil nutrition by boric acid in field experiments at 2018 did not show any phytotoxicity effects at $17.5 \mathrm{~kg} / \mathrm{ha}$ (Table 3 ). Even at potentially high levels of borate leaching, when boric acid was applied to the soil early in spring, the yield level of the variant with the soil application of borate significantly prevailed over one under borate foliar application. It should be noted that in the experiments boron was applied in foliar nutrition twice at $1.0 \mathrm{~kg} / \mathrm{ha}$, which is the maximum dose of boron fertilizers used in holdings for large areas of boron-dependent crops.

TABLE 4. Boron fertilizers effect on sunflower when applied in the soil (2019)

\begin{tabular}{l|c|c}
\hline \multirow{2}{*}{ Boron fertilizer } & \multicolumn{2}{c}{ Yield, t/ha } \\
\cline { 2 - 3 } Control & $2.56 \pm 0.15$ & Vinnytsia region \\
Etidot-67, soil & $2.91 \pm 0.04$ & $3.94 \pm 0.01$ \\
Borax powder & $2.94 \pm 0.02$ & $4.08 \pm 0.05$ \\
Colemanite & $3.16 \pm 0.15$ & $4.06 \pm 0.05$ \\
Ulexite & $3.27 \pm 0.16$ & $4.40 \pm 0.13$ \\
Borax granular & $3.05 \pm 0.06$ & $4.68 \pm 0.36$ \\
Boric acid & $2.91 \pm 0.09$ & $4.05 \pm 0.02$ \\
Etidot-67, 2 foliar & $3.10 \pm 0.04$ & $4.10 \pm 0.04$ \\
LSD $_{0.05}$ & 0.31 & $3.98 \pm 0.04$ \\
\end{tabular}


In 2019 season the effectiveness of the most perspective for Ukrainian market boric mineral fertilizers for soil application was studied. Regarding the soil application of boron fertilizers under the conditions of experiments in Kyiv and Vinnytsia regions, the highest levels of sunflower productivity were achieved with Colemanite and Ulexite application (Table 4). It should be noted that the efficiency of these fertilizers exceeded the effect of boric acid and Etidot-67; the latter is the fertilizer for conditions of the soil and foliar application.

Thus, the use of boron fertilizers for plant growing in Ukraine is important to improvement the productivity of boron-sensitive crops, foremost sunflower. The introduction of slowly soluble boric fertilizers (Colemanite, Ulexite, etc) for the soil application will significantly reduce damage to the seedlings from phytotoxic effects of boron, and rise its efficiency for cultivated plants productivity increasing.

\section{REFERENCES}

1. Warington, K. (1923). The effect of boric acid and borax on the broad been and certain other plants. Ann Bot., 37, 4, pp. 629-672. https://doi.org/10.1093/oxfordjournals. aob.a089871

2. Marschner, H. (2012). Marschner's Mineral Nutrition of Higher Plants. London: Academic Press.

3. Lemarchand, D., Gaillardet, J., Lewin, E. \& Allegre C.J. (2000). The influence of rivers on marine boron isotopes and implications for reconstructing past ocean $\mathrm{pH}$. Nature 408 (6815), 951-954. https://doi.org/10.1038/35050058

4. Gupta U.C. (1993). Factors affecting boron uptake by plants. In: Gupta UC, ed. Boron and its role in crop production Boca Raton, FL: CRC Press, Inc., 87-104.

5. National Soil Fertility Report, 2010. http://www.iogu.gov.ua/wp-content/uploads/2013/ 07/stan_gruntiv.pdf

6. Cakmak, I. \& Romheld, V. (1997). Boron deficiency-induced impairments of cellular functions in plants. Plant Soil, 193, pp. 71-83. https://doi.org/10.1023/ A: 1004259808322

7. Dear, B.S. \& Weir, R.G. (2004). Boron deficiency in pastures and field crops. New South Wales Department of Agriculture Agfacts, P1.AC.1, 2nd Ed. pp. 1-8. www.agric.nsv.gov.au

8. Putoczki, T., Gerrard, J. \& Jackson, S. (2007). Physiology and Metabalism of Boron in Plants. In: XU F. Goldbach, H., Brown, P.H., Bell, R.W., Fujiwara, T., Hunt, C.D., Goldberg, S., Shi, L. (eds). Advances in Plant and Animal Boron Nutrition. Springer: Dordrecht.

9. Diehn, T.A., Bienert, M.D., Pommerrenig, B., Liu, Z., Spitzer, C., Bernhardt, N., Fuge, J., Bieber, A., Richet, N., Chaumont, F. \& Bienert, G.P. (2019). Boron demanding tissues of Brassica napus express specific sets of functional Nodulin26-like Intrinsic Proteins and BOR1 transporters. Plant J., 100, pp. 68-82. https://doi.org/ $10.1111 /$ tpj. 14428

10. WHO (World Health Organization) (1998). Environmental health criteria 204: Boron. International programme on chemical safety, Geneva, Switzerland.

11. Kabu, Mustafa \& Akosman, Murat. (2013). Biological effects of boron. Reviews of Environmental Contamination and Toxicology, 225, pp. 57-75. https://doi.org/10.1007/ 978-1-4614-6470-9_2

12. Bolanos, L., Lukaszewski, K., Bonilla, I. \& Blevins, D. (2004). Why boron? Plant Physiology and Biochemistry, 42, 11, pp. 907-912. https://doi.org/10.1016/j.plaphy.2004.11.002

13. Brown, P.H., Bellaloui, N., Wimmer, M.A., Bassil, E.S., Ruiz, J., Hu, H., Pfeffer, H., Dannel, F. \& Romheld, V. (2008). Boron in plant biology. Plant Biol., 4 (2), pp. 205223. https://doi.org/10.1055/s-2002-25740

14. Moing, A, Carbonne, F, Rashad, M.H. \& Gaudilere, J.P. (1992). Carbon fluxes in mature peach leaves. Plant Physiology, 100, pp. 1878-1884. 
15. Nielsen, F.H. \& Meacham, S.L. (2011). Growing evidence for human health benefits of boron. J. Evid. Based Integr. Medicine, 16, pp. 169-180.

16. Shaaban, M.M. (2010). Role of Boron in Plant Nutrition and Human Health. American J. Plant Physiol., 5, 5, pp. 224-240. https://doi.org/10.3923/ajpp.2010.224.24

17. Waqar, A., Niaz, A, Kanwal, S. \& Khalid, M. (2009). Role of boron in plant growth: a review. J. Agricult. Res., 47 (3), pp. 329-338.

18. Landi, M., Margaritopoulou, Th., Papadakis, I.E. \& Araniti, F. (2019). Boron toxicity in higher plants: an update. Planta, 250, pp. 1011-1032. https://doi.org/10.1007/s00425019-03220-4

19. Blevins, D.J. \& Lukaszewski, K.M. (1998). Boron in plant structure and function. Annu. Rev. Plant Physiol. Plant Mol. Biol., 49, pp. 481-500.

20. Reid, R. (2014). Understanding the boron transport network in plants. Plant Soil, 385 (1-2), pp. 1-13. https://doi.org/10.1007/s11104-014-2149-y

21. Princi, M.P., Lupini, A., Araniti, F., Longo, C., Mauceri, A., Sunseri, F. \& Abenavoli, M.R. (2016). Boron toxicity and tolerance in plants: recent advances and future perspectives. Plant Metal Interaction. Elsevier, Amsterdam, pp. 115-147. https://doi.org/10.1016/B978-0-12-803158-2.00005-9

22. Will, S., Eichert, T., Fernandez, V., Mohring, J., Muller, T. \& Romheld, V. (2011). Absorption and mobility of foliar-applied boron in soybean as affected by plant boron status and application as a polyol complex. Plant Soil, 344 (1-2), pp. 283-293.

Received 10.03.2020

\title{
ФізЗіОЛОГіЧНІ ОСОБЛИВОСТї ЖИВЛЕННЯ СОНЯШНИКА БОРНИМИ ДОБРИВАМИ
}

\author{
В.В. Моргун ${ }^{1}$, I. Чакмакㄹ, В.В. Швартау ${ }^{1}$, Л.М. Михальська ${ }^{1}$ \\ ${ }^{1}$ Їнститут фізіології рослин і генетики Національної академії наук України \\ 03022 Київ, вул. Васильківська, 31/17 \\ ${ }^{2}$ Університет Сабанчі, Їнженерно-природничий факультет \\ 34956 Тузла, Стамбул, Туреччина \\ e-mail: victorschwartau@gmail.com
}

Хоча важливість бору у живленні рослин встановлено майже сторіччя тому, фізіологічні особливості прояву активності елемента все ще належать до проблем, що обговорюються. Ринок борних добрив в Україні перевантажений рекламними пропозиціями, при цьому практично відсутні результати дослідів з визначення ефективності борних добрив на посівах культурних рослин. Традиційно, з початку 1990-х років, основна увага в живленні рослин в Україні приділяється азоту. Однак низький рівень використання азоту сільськогосподарськими культурами вказує на те, що інформації про фізіологічні механізми живлення культурних рослин недостатньо й інші елементи можуть впливати на ефективність систем живлення та рентабельність вирощування культурних рослин. Питання живлення культурних рослин іншими важливими елементами, насамперед бором, залишаються поза увагою. В Україні площі під борзалежними культурами перевишують 10 млн га: соняшник, озимий і ярий ріпак, цукрові буряки, картопля тощо. Бор в системах живлення також необхідний для сої, зернових колосових і кукурудзи. Дефіцит бору у культурних рослин спостерігається в усіх грунтово-кліматичних зонах України. Метою цього дослідження було з'ясувати ефективність перспективних для України форм борних мінеральних добрив для живлення соняшника, культури, яка займає найбільші посівні площі в країні як серед усіх культур, так і серед борзалежних. Дослідження показали, що використання борних добрив у рослинництві України є важливим для підвищення продуктивності соняшника. Впровадження у системи живлення повільнорозчинних борних добрив (колеманіт, улексит тощо) в основне внесення істотно знижує фітотоксичність бору для сходів і підвищує продуктивність соняшника, а також перспективне для інших борзалежних культурних рослин.

Ключові слова: бор, соняшник, врожай, фітотоксичність. 